\title{
Does the consumption of amylase-containing gruels impact on the energy intake and growth of Congolese infants?
}

\author{
M Moursi ${ }^{1}$, F Mbemba $^{2}$ and S Trèche ${ }^{1, *}$ \\ ${ }^{1}$ NNutrition, Alimentation, Sociétés' Research Unit, Institut de Recherche pour le Développement, UR 106, BP 64501, \\ F-34394 Montpellier Cedex 5, France: ${ }^{2}$ University Marien Ngouabi, Brazzaville, Republic of the Congo
}

\section{Submitted 15 July 2002: Accepted 10 0ctober 2002}

\begin{abstract}
Objective: To assess the effect of the incorporation of amylase in maize-based flours prepared as gruels on the energy intake and growth of Congolese infants.

Design: A randomised controlled trial. At 18 weeks of age, infants were randomised into either an intervention group, where they were provided with a maize/soya-based flour that contained amylase, or a control group, where they were provided with a similar flour that did not contain amylase.

Setting: Urban borough of Poto-Poto in Brazzaville, The Congo.

Subjects: Eighty infants (40 in each group) were randomised into intervention and control groups. Three infants in the intervention group and two controls subsequently dropped out.

Results: At 24 weeks, the addition of amylase resulted in a significant increase in energy intake (in $\left.\mathrm{kJ} \mathrm{kg}^{-1} \mathrm{day}^{-1}\right)$ from gruels $(P=0.02)$ without affecting breast milk consumption. In contrast, total energy intake (in $\mathrm{kJ} \mathrm{kg}^{-1} \mathrm{day}^{-1}$ ) did not differ significantly between groups $(P=0.08)$. After adjustment for morbidity and previous growth, infants in the intervention group showed better growth in length during the trial $\left(+0.22 \mathrm{~cm} \mathrm{month}^{-1} ; P=0.04\right)$, especially between 24 and 31 weeks of age $\left(+0.51 \mathrm{~cm} \mathrm{month}^{-1} ; P<0.01\right)$. There were no differences in weight velocity between groups.

Conclusions: The findings of this study suggest that the consumption of amylasetreated gruels allows an increase in energy intake from these gruels without affecting breast milk consumption but has no impact on total daily energy intake. However, if started after 6 months, it could be effective in preventing faltering of infant linear growth.
\end{abstract}

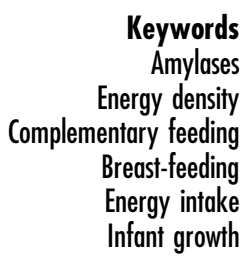

In developing countries, the growth rates of infants who are exclusively breast-fed during the first 6 months are similar to those of their counterparts in affluent populations ${ }^{1-3}$. After this period, most infants in developing countries deviate from the satisfactory growth pattern due to recurrent infections and a lack of nutrientdense complementary foods ${ }^{4}$.

Mothers in most developing countries traditionally use gruels as the first special transitional food. These are generally prepared from a fermented dough or a flour or mixture of flours that are produced locally. These flours typically have high starch content and, when cooked in water, they swell considerably and thicken the gruels. In order to avoid this thickening, mothers reduce the proportion of flour to water and as a result the energy and nutrient densities of the gruels become insufficient. Low-nutrient-density complementary foods play an important role in children's dietary intake and growth performance ${ }^{3}$. Complementary foods with low nutritional value could displace breast milk and consequently have a detrimental effect on the nutritional status of infants ${ }^{3}$.

Modification of the dietary characteristics of bulky gruels has been used as a way to improve children's dietary intake and several studies have been carried out to assess the effect of modifying the viscosity and/or energy density on infants' energy intake. Since the underlying problem is the low energy and nutrient densities of watery gruels, and bearing in mind the relationship between consistency and energy density, these studies aimed to answer two main questions. The first question is whether increasing the energy density of gruels increases energy intake. In studies addressing this question, gruels of the same consistency but with different energy densities were compared and the findings were consistently positive ${ }^{5-15}$. The second question is whether reducing the bulk or thinning down high-viscosity gruels increases energy intake. In this case, high- and low-viscosity gruels were compared while keeping the energy density constant. 
The results of these studies are not consistent, some findings being positive $\mathrm{e}^{8,12,15-19}$ and others not ${ }^{5,9,20}$.

In all of the aforementioned studies but one ${ }^{7}$, amylase was used as a way to increase the density of energy and other nutrients while keeping the gruels' consistency at levels acceptable to both infants and mothers. These studies differed methodologically, as their objectives were not the same. Although the designs of most of them were appropriate to the questions being asked, it may not be possible to apply the results to normal living conditions for several reasons. First, most studies, especially the most recent ones, were conducted on non-breast-fed subjects recovering from severe or moderately severe malnutrition in hospital wards, where the infants were rarely fed by their mothers. In addition, in some contexts the recipes developed for some of these studies are not easily reproduced in normal living conditions and some ingredients used are not readily available or accessible. Finally, the study meals were often offered three to five times per day, which is higher than the mean meal frequency of infants of two meals per day observed in most African countries ${ }^{21}$.

In fact, from an operational point of view, the question is whether it is possible to improve the intake of energy and other nutrients as well as the growth of infants if they consume gruels prepared using processes that allow modification of the relationship between consistency and energy density.

The present study was designed to assess the effect on energy intake of infants in normal living conditions of adding amylase to a maize/soya-based flour, a typical blend used in several African countries for the preparation of gruels. The main hypothesis was that, under normal living conditions, the addition of amylase to the flour would allow an increase in the energy and nutrient intakes of infants without affecting breast milk intake. Adding amylase was also expected to have a positive impact on growth.

\section{Methods}

\section{Study design}

The present study was a controlled trial in which two groups of infants were randomly assigned on an individual basis to receive either a maize/soya-based flour to which an industrial amylase was added (intervention group) or a similar flour without amylase (control group). At the beginning of the distribution period, the mothers in each group were shown individually once what amounts of flour and water to use in order to obtain gruels of similar consistency to the ones they were used to preparing. Aside from this single demonstration, there were no special instructions for the use of flours and mothers were free to modify the original recipe if they felt like doing so.

Four trained female assistants collected the data for the study. Data on anthropometry, breast-feeding practice, morbidity and socio-economic factors were collected starting when the infants were 10 weeks old. The distribution of flours with and without added amylase started at 18 weeks of age, after having made sure that the parents had already spontaneously introduced complementary foods, and continued for 14 weeks. Intakes of complementary foods and breast milk were assessed at 24 weeks of age.

Ethical approval was obtained from the Ministry of Health of the Republic of the Congo. Parents were informed about the study and gave their consent.

\section{Sample size calculation}

Sample size was calculated in order to detect a two-sided, $15 \%$ difference in energy intake from gruels prepared with the aforementioned flours with 90\% power and $\alpha=5 \%$. This difference is equivalent to $50 \mathrm{~kJ}$ per kg of body weight per day based on a mean energy intake of $314 \mathrm{~kJ} \mathrm{~kg}^{-1}$. day $^{-1}$ and a standard deviation (SD) of $67 \mathrm{~kJ} \mathrm{~kg}^{-1}$ day ${ }^{-1}$, which were observed in a previous study carried out in 1993 in the same area on 50 infants of the same age ${ }^{22}$. The estimated sample size required was 40 in each group after allowing for a $5 \%$ dropout.

\section{Sample recruitment}

The study was carried out between June 1995 and February 1996 in the borough of Poto-Poto in Brazzaville (The Congo), where the prevalence of stunting (heightfor-age $<-2$ SD from the National Center for Health Statistics (NCHS) median) of children $<2$ years old was relatively high for an urban context $(15.5 \%)^{23}$. Mothers introduced complementary foods at an early age since 50\% of infants consumed gruels at the age of 13 weeks. Their mean frequency of gruel meal per day was low: $25 \%$ of infants were given one gruel meal per day, 54\% were given two and $21 \%$ more than two ${ }^{24}$.

The selection criteria for infants were as follows: infants had to be singletons; to have a birth weight $>2500 \mathrm{~g}$; be brought up and breast-fed by their mothers at home; to have a weight-for-length $Z$-score $>-2$ at 16 weeks; not to have been hospitalised for serious illnesses, which could have a significant impact on their nutritional status; not to have malformations; the mother or carer should not intend to be absent for more than one week during the study; and parents had to consent to the presence of a trained assistant in their house for 24 hours when the child reached the age of 16 and 24 weeks and also accept weekly visits for collection of morbidity data.

The research team completed a census of an area in the borough of Poto-Poto to identify all mothers of children who would be aged 10 weeks or less before the start of the study. Out of the 132 mothers identified, five refused to participate and 13 were not considered eligible mainly because of intended prolonged absence during the study. The participants were selected randomly from among the remaining mothers and enrolled progressively over a 
period of 8 weeks. Infants who did not participate in the study had similar birth weights to those who did $(P=0.10)$.

\section{Study flours}

The main characteristics of these flours are shown in Table 1. In order to obtain gruels of similar sweetness while keeping the nutrient content similar, more sugar had to be added to the formula of the flour without amylase. This changed its composition slightly compared with the amylase-containing flour. Indeed, when amylase comes into action, it breaks down starch into oligosaccharides that increase sweetness. The increased sweet taste is also due to the fact that less water is added during the preparation of amylase-containing gruels.

\section{Antbropometry}

Anthropometric measurements were collected at the subjects' homes according to standardised protocols at 10, 16, 24 and 32 weeks of age. Infants were weighed naked on a mechanical baby scale (Seca, Hamburg, Germany; precision $\pm 10 \mathrm{~g}$ ). Length was measured to the nearest $0.1 \mathrm{~cm}$ using a Holtain infantometer (Holtain Limited, Crymych, UK). For the purpose of analysis, length velocity was calculated during the following time periods: 10-15, 16-23, 24-31 and 16-31 weeks of age. As length velocity in a given period was inversely correlated with length velocity in the period that immediately preceded it (results not shown), it had to be adjusted for in the statistical analysis ${ }^{25}$. We used a multiple regression model similar to the one used by Victora et ll $^{25}$. This approach also allowed adjustment for the bias of regression to the mean, which can affect repeated surveys.

\section{Morbidity}

Infant morbidity data were collected weekly starting at the age of 10 weeks and throughout the study period. Mothers

Table 1 Composition and nutrient content per $100 \mathrm{~g}$ dry matter of study flours

\begin{tabular}{lcc}
\hline & $\begin{array}{c}\text { Flour without } \\
\text { amylase }\end{array}$ & Flour with amylase \\
\hline Maize flour (g) & 60.5 & 72.9 \\
Soya flour (g) & 19.9 & 15.0 \\
Sugar (g) & 18.5 & 11.0 \\
Mineral complement ${ }^{\star}(\mathrm{g})$ & 1.0 & 1.0 \\
Vitamin complement† (g) $_{\text {Amylaseł (mg) }}$ & 0.1 & 0.1 \\
Energy in kJ (kcal) & - & 33.7 \\
Protein (g) & $1741(416)$ & $1724(412)$ \\
Iron (mg) & 13.6 & 14.6 \\
Calcium (mg) & 8.4 & 9.4 \\
Phosphorus (mg) & 326 & 312 \\
Zinc (mg) & 334 & 341 \\
& 2.8 & 3.0
\end{tabular}

* Content of the mineral complement (per g): $300 \mathrm{mg} \mathrm{Ca}, 16 \mathrm{mg} \mathrm{Mg}, 4 \mathrm{mg}$ $\mathrm{Fe}, 2 \mathrm{mg} \mathrm{Zn}, 0.17 \mathrm{mg} \mathrm{Cu}$ and $61 \mu \mathrm{g} \mathrm{I}$.

† Content of the vitamin complement (per g): $176 \mathrm{mg}$ vitamin $\mathrm{C}, 16 \mathrm{mg}$ vitamin $A, 16 \mathrm{mg}$ vitamin $D_{3}, 0.15 \mathrm{mg}$ folate, $125 \mu \mathrm{g}$ vitamin $K_{1}$ and $4.4 \mu \mathrm{g}$ vitamin $\mathrm{B}_{12}$.

$\ddagger$ Industrial alpha-amylase (BAN 800; Novoenzymes A/S, Bagsvaerd, Denmark). were asked to recall symptoms of fever, loss of appetite, respiratory illness, skin disease, diarrhoea or any other symptom of illness that did not fit into these categories. They also had to indicate the day the illness started and ended. Fever was based on the mother's report of elevation of infant's body temperature above normal, loss of appetite and diarrhoea (defined as three liquid stools or more during a 24-hour period) were based on the mother's perception, and respiratory illness was defined as the presence of purulent nasal discharge (rhinitis) and/or cough for two consecutive days or more. For the purpose of analysis, the study period was divided into four time intervals: $10-15,16-23,24-31$ and 16-31 weeks of age. The prevalence of a disease was calculated as the number of days of illness reported during the specified time intervals divided by the number of days in these time intervals; the result was expressed as a percentage. The incidence of a disease was calculated as the number of new episodes per 100 days at risk (excluding missing days and days with illness).

\section{Dietary assessment}

Consumption of complementary foods was assessed at the age of 24 weeks using a 24-hour observed weighed food record. The observers recorded and weighed all foods and beverages consumed by the infant during a 24-hour period using electronic scales (precision $1 \mathrm{~g}$ ). Any losses by vomiting or spilling on the ground or on the child's clothes were recorded and corrections of intakes were made.

In order to avoid major sources of variation in values of energy content, representative samples of foods were taken at each meal to determine the dry matter content used in the calculation of energy content. Energy contents of foods applied in calculations were those that were determined by chemical analysis in the 1993 study $^{22}$ in the same borough of Poto-Poto. Energy contents of some foods consumed in this study that had not been analysed previously were estimated using food composition tables ${ }^{26}$.

Breast milk intake was measured over a 24-hour period using the test weighing technique $e^{27,28}$ at 24 weeks of age. Infants were weighed twice before and twice after breastfeeding using an electronic scale with a precision of $1 \mathrm{~g}$ (Mettler, Greifensee, Switzerland). Vomiting during or after nursing was recorded and taken into account in the calculations. Mothers were asked to wear tee shirts and bras during the night to avoid breast-feeding without being aware of it. If the child wanted to breast-feed during the night, his or her cries would wake up the mother and the mother was asked to wake up the observer. The energy content of breast milk applied for the calculations ( $244.8 \mathrm{~kJ} / 100 \mathrm{ml} ; 58.5 \mathrm{kcal} / 100 \mathrm{ml}$ ) was based on chemical analysis of expressed breast milk in the 1993 study.

\section{Statistical analysis}

$Z$-scores were calculated using the Epinut module of Epi Info version 6.04d (Centers for Disease Control 
and Prevention, Atlanta, GA, USA). Statistical analysis was performed using Stata release 7.0 (Stata Corporation, College Station, TX, USA). Normality of the data was checked using a combination of several normality tests: chi-square test for normality of the data, Shapiro-Wilks and Kolmogorov-Smirnov tests for the equality of distribution test. Data that were not normally distributed are presented as medians, 25th and 75th percentiles, which are more appropriate for summarising skewed distributions.

Student's $t$-test and Mann-Whitney tests were used to compare means while the chi-square test was used to compare proportions. Adjustments for baseline differences were made using multivariate linear regression. In all comparisons, the level of statistical significance was set at 0.05 .

\section{Results}

Eighty infants initially participated in the study but five (three in the intervention group and two in the control group) dropped out after the age of 16 weeks. Of those who dropped out, four did so because their parents moved away and one child died.

Mother and child characteristics, breast-feeding practices, morbidity and length velocity of the remaining infants were compared before the start of the study and there were no significant differences (see Table 2). No differences were found between groups in maternal height and birth weight.

\section{Morbidity}

There was no significant variation in the percentage of days ill and the incidence of diseases between the intervention and control groups during all time intervals with the exception of respiratory illness between 16-23 and 16-31 weeks of age (see Table 3). Indeed, during these periods, the percentage of days ill with cough or rhinitis and their incidence were significantly higher in the intervention group. These differences were accounted for during the analysis of growth data. Illnesses that could be related to the consumption of amylase-containing flour such as diarrhoea and skin disease as a symptom of allergy were checked during the entire intervention period and no differences were found between groups.

\section{Characteristics of the gruels}

Since mothers were free to prepare gruels as they liked and use their own recipes, additional ingredients were sometimes used. The proportion of mothers who prepared flours with additional ingredients was $45 \%$ and $70 \%$ in the intervention and control groups, respectively $(P=0.18)$. The main additional ingredients were sugar (added in 59\% of gruels), condensed milk (23\%) and whole powdered milk (20\%). Each of these ingredients was added alone or in combination with the others.
Table 2 Infants' and mothers' characteristics in intervention and control groups

\begin{tabular}{|c|c|c|c|}
\hline & $\begin{array}{l}\text { Intervention } \\
\text { group } \\
(n=37)\end{array}$ & $\begin{array}{l}\text { Control } \\
\text { group } \\
(n=38)\end{array}$ & $P$-value \\
\hline $\begin{array}{l}\text { Gender } \\
\text { Male } \\
\text { Female }\end{array}$ & $\begin{array}{l}18(49 \%) \\
19(51 \%)\end{array}$ & $\begin{array}{l}19(50 \%) \\
19(50 \%)\end{array}$ & 0.95 \\
\hline $\begin{array}{l}\text { Birth weight }(\mathrm{g}) \\
\text { Mean } \pm \mathrm{SD}\end{array}$ & $3037 \pm 307$ & $2983 \pm 424$ & 0.51 \\
\hline $\begin{array}{l}\text { Weight at } 16 \text { weeks }(\mathrm{kg}) \\
\text { Mean } \pm \mathrm{SD}\end{array}$ & $6.17 \pm 0.12$ & $6.16 \pm 0.12$ & 0.94 \\
\hline $\begin{array}{l}\text { Length at } 16 \text { weeks }(\mathrm{cm}) \\
\text { Mean } \pm \text { SD }\end{array}$ & $61.0 \pm 2.2$ & $61.6 \pm 2.2$ & 0.25 \\
\hline $\begin{array}{l}\text { Length-for-age } Z \text {-score at } 1 \\
\text { Mean } \pm \text { SD }\end{array}$ & $\begin{array}{l}6 \text { weeks } \\
-0.02 \pm 0.88\end{array}$ & $-0.27 \pm 0.82$ & 0.23 \\
\hline $\begin{array}{l}\text { Weight-for-height } Z \text {-score a } \\
\text { Mean } \pm \text { SD }\end{array}$ & $\begin{array}{l}16 \text { weeks } \\
0.14 \pm 0.76\end{array}$ & $0.38 \pm 0.61$ & 0.14 \\
\hline $\begin{array}{l}\text { Length velocity at } 10-15 \mathrm{w} \\
\text { Mean } \pm \text { SD }\end{array}$ & $\begin{array}{l}\text { eks of age }(\mathrm{cm} \\
3.08 \pm 0.90\end{array}$ & $\begin{array}{l}\left.\text { month }^{-1}\right) \\
\quad 3.32 \pm 0.94\end{array}$ & 0.39 \\
\hline $\begin{array}{l}\text { Breast-feeding frequency a } \\
\text { Mean } \pm \text { SD }\end{array}$ & $\begin{array}{c}16 \text { weeks of ag } \\
9.9 \pm 3.2\end{array}$ & $\begin{array}{l}\text { ge (times per da } \\
9.5 \pm 3.2\end{array}$ & $\begin{array}{l}\text { ay) } \\
0.61\end{array}$ \\
\hline $\begin{array}{l}\text { Morbidity at } 10-15 \text { weeks } \\
\text { Mean \% days ill }(95 \% \mathrm{Cl}\end{array}$ & $\begin{array}{l}f \text { age } \\
57(25-89)\end{array}$ & $52(16-90)$ & 0.48 \\
\hline $\begin{array}{l}\text { Maternal age (years) } \\
\text { Mean } \pm \text { SD }\end{array}$ & $26.1 \pm 1.0$ & $25.9 \pm 1.1$ & 0.90 \\
\hline $\begin{array}{l}\text { Maternal height }(\mathrm{cm}) \\
\text { Mean } \pm S D\end{array}$ & $160.7 \pm 5.0$ & $161.4 \pm 6.3$ & 0.67 \\
\hline $\begin{array}{l}\text { Maternal BMI }\left(\mathrm{kg} \mathrm{m}^{-2}\right) \\
\text { Mean } \pm \mathrm{SD}\end{array}$ & $22.5 \pm 4.5$ & $22.2 \pm 3.8$ & 0.76 \\
\hline $\begin{array}{l}\text { Maternal education (years } \\
\text { Mean } \pm \text { SD }\end{array}$ & $\begin{array}{l}\text { schooling) } \\
10.3 \pm 2.0\end{array}$ & $10.1 \pm 2.6$ & 0.74 \\
\hline $\begin{array}{l}\text { Household size (number } \\
\text { Mean } \pm \text { SD }\end{array}$ & $\begin{array}{l}\text { ersons) } \\
\qquad 7.0 \pm 4.7\end{array}$ & $7.4 \pm 3.9$ & 0.71 \\
\hline
\end{tabular}

$\mathrm{SD}$ - standard deviation; $\mathrm{Cl}$ - confidence interval; BMI - body mass index.

The median energy density of gruels prepared without additional ingredients by mothers in the intervention group was $110 \%$ higher $(P<0.01)$ than the median energy density of gruels prepared by mothers in the control group (see Table 4). The analysis was repeated on gruels that were prepared with additional ingredients and the median energy density was 90\% higher in the intervention group $(P<0.01)$. Additional ingredients contributed in similar amounts to the total energy density of gruels in each group: their addition resulted in 75 and $63 \mathrm{~kJ}$ per $100 \mathrm{~g}$ of gruel in the intervention and control group, respectively $(P=0.14)$.

\section{Dietary intake at 24 weeks}

Breast-feeding prevalence at 24 weeks was $100 \%$ and $92 \%$ respectively in the intervention and control group $(P=0.09)$. Nursing frequency and duration as well as breast milk intake at the age of 24 weeks are shown for each group in Table 5. Comparisons between the groups at 24 weeks of age showed no statistically significant differences. 
Table 3 Days ill and morbidity incidence of infants in intervention and control groups (mean \pm SD)

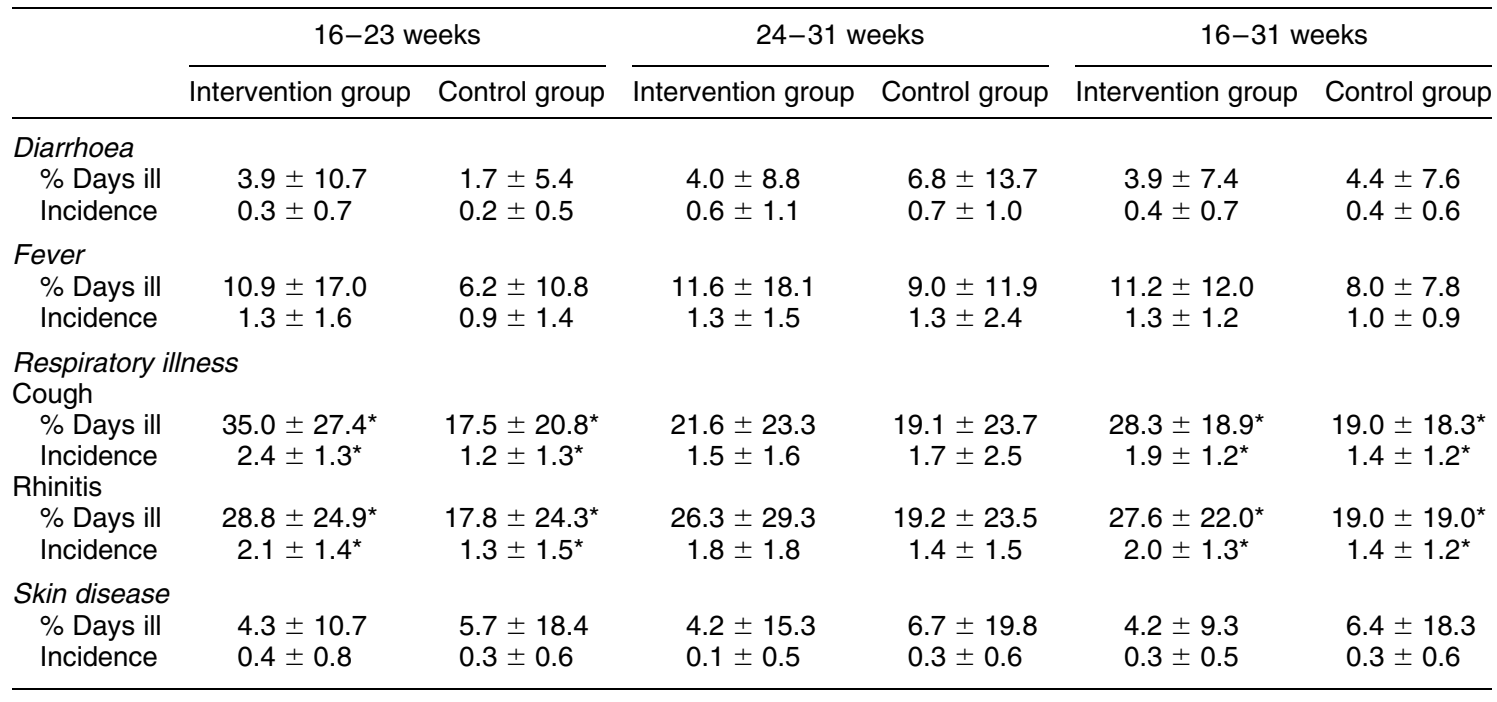

SD - standard deviation; \% days ill - number of days with illness/total number of days of observation in the specified time interval, expressed as a percentage; incidence - number of new episodes/100 days at risk.

${ }^{*}$ Groups are significantly different at the 0.05 level.

Energy intakes by food source at 24 weeks of age are shown in Table 6. Thirty-one infants in the intervention group (84\%) and 33 in the control group (87\%) consumed gruels prepared with respectively the intervention or control flour at least once a day during the 24-hour survey. Infants in the intervention group had a $52 \%$ higher median energy intake (expressed in $\mathrm{kJ} \mathrm{kg}^{-1} \mathrm{day}^{-1}$ ) from gruels prepared with the amylase-containing flour $(P=0.02)$. The mean number of gruel feeds per day was 2.1 (SD 0.8) and 2.2 (SD 0.8) in the intervention and control group, respectively.

Since an infant's health status can greatly affect his/her appetite, the occurrence or presence of illnesses in the five days preceding the dietary survey at 24 weeks of age was checked and no differences were found between groups.

Twenty infants in each group consumed complementary foods other than the gruels prepared with the study flours. Energy intake from other complementary foods (in $\mathrm{kJ} \mathrm{kg}^{-1} \mathrm{day}^{-1}$ ) did not differ significantly between groups $(P=0.67)$. Energy intake from breast milk (in $\mathrm{kJ} \mathrm{kg}^{-1}$ $\left.\mathrm{day}^{-1}\right)$ remained at similar levels in the two groups $(P=$ $0.73)$. The difference in total daily energy consumption $\left(\mathrm{kJ} \mathrm{kg}^{-1} \mathrm{day}^{-1}\right)$ did not reach the level of statistical significance $(P=0.08)$.

\section{Growth velocity}

As shown in Table 7, length velocity varied in two opposite ways in the intervention and control groups during the 16-23 and 24-31 weeks time intervals. After adjustment for morbidity and previous growth, the difference in length velocity, which was greater in the control group during the 16-23 weeks time interval (0.36 $\left.\mathrm{cm} \mathrm{month}^{-1} ; P=0.03\right)$, became greater in the intervention group between 24 and 32 weeks of age $\left(0.51 \mathrm{~cm} \mathrm{month}^{-1} ; P<0.01\right)$. Infants in the intervention group had a higher length velocity between 16 and 32 weeks of age $(P=0.04)$ after adjustment for morbidity and previous growth. There were no differences in weight velocity between groups during any of the time intervals.

\section{Discussion}

The study shows that, in normal living conditions where mothers choose their preferred consistency, the energy density of gruels prepared with amylase-containing flour is considerably higher than the energy density of gruels prepared with a similar flour without amylase. The differences observed in energy density are due to the fact that it was possible for mothers in the intervention group

Table 4 Characteristics of gruels prepared by mothers of infants at 24 weeks

\begin{tabular}{|c|c|c|c|c|c|}
\hline & \multicolumn{2}{|c|}{ Intervention group } & \multicolumn{2}{|c|}{ Control group } & \multirow[b]{2}{*}{$P$-value } \\
\hline & Median & 25th-75th percentile & Median & 25th-75th percentile & \\
\hline \multicolumn{6}{|l|}{ Without additional ingredients } \\
\hline Number of gruel meals consumed & & $n=36$ & & $n=19$ & \\
\hline $\begin{array}{l}\text { Energy density }(\mathrm{kJ} / 100 \mathrm{~g}) \\
\text { With additional ingredients }\end{array}$ & 448 & $385-502$ & 213 & 205-239 & $<0.01$ \\
\hline \multicolumn{6}{|l|}{ With additional ingredients } \\
\hline Total energy density $(\mathrm{kJ} / 100 \mathrm{~g})$ & 565 & $506-649$ & 297 & $268-3390$ & $<0.01$ \\
\hline
\end{tabular}


Table 5 Breast-feeding practices and breast milk intake at 24 weeks of age (mean \pm SD)

\begin{tabular}{|c|c|c|c|}
\hline & $\begin{array}{l}\text { Intervention } \\
\quad(n=37)\end{array}$ & $\begin{array}{l}\text { Control } \\
(n=38)\end{array}$ & $P$-value \\
\hline Breast-fed infants & $37(100 \%)$ & $35(92 \%)$ & 0.09 \\
\hline Feeding frequency (times day ${ }^{-1}$ ) & $7.4 \pm 3.5$ & $6.2 \pm 3.2$ & 0.14 \\
\hline Duration $\left(\min ^{\prime}\right.$ feed $\left.{ }^{-1}\right)$ & $8.1 \pm 4.2$ & $8.0 \pm 4.7$ & 0.98 \\
\hline Breast milk intake $\left(\mathrm{g}^{\prime}\right.$ feed $\left.{ }^{-1}\right)$ & $54.4 \pm 32.6$ & $60.8 \pm 37.1$ & 0.12 \\
\hline Breast milk intake $\left(\mathrm{g} \mathrm{day}^{-1}\right)$ & $401 \pm 212$ & $375 \pm 194$ & 0.58 \\
\hline
\end{tabular}

SD - standard deviation.

to add more flour during the preparation of gruels as a result of the liquefying action of the amylase. The energy density of amylase-containing gruels increased by $110 \%$ when they were prepared without additional ingredients and by $90 \%$ when additional ingredients were used. According to the World Health Organization ${ }^{3}$, the recommended energy density required to reach the minimum level of energy needed from complementary foods in two meals per day and with a low level of breast milk intake is $536 \mathrm{~kJ} / 100 \mathrm{~g}(128 \mathrm{kcal} / 100 \mathrm{~g})$. The use of amylase allowed mothers to prepare gruels with energy densities close to the recommendations and to even exceed them when additional ingredients were used.

There were no significant differences between groups regarding breast-feeding practices and breast milk intake. Infants in both intervention and control groups consumed considerably lower amounts of breast milk per day than their counterparts in most other developing countries. Mean intake of breast milk was 401 (SD 212) $\mathrm{g} \mathrm{day}^{-1}$ and 375 (SD 194) $\mathrm{g} \mathrm{day}^{-1}$ in the intervention and control group, respectively. These intakes represent respectively $54 \%$ and $51 \%$ of the average pooled estimation of intakes
Table 6 Energy intake by food source of 24-week-old infants

\begin{tabular}{|c|c|c|c|}
\hline Food source & $\begin{array}{l}\text { Intervention } \\
\text { group }(n=37)\end{array}$ & $\begin{array}{c}\text { Control } \\
\text { group }(n=38)\end{array}$ & $P$-value \\
\hline \multicolumn{4}{|c|}{ Study gruels, median (25th-75th percentile) } \\
\hline $\begin{array}{l}\mathrm{kJ} \mathrm{day}^{-1} \\
\mathrm{~kJ} \mathrm{~kg}^{-1} \text { day }^{-1}\end{array}$ & $\begin{array}{c}1117(490-1528) \\
155(79-213)\end{array}$ & $\begin{array}{l}682(456-1155) \\
102(61-159)\end{array}$ & $\begin{array}{l}0.03 \\
0.02\end{array}$ \\
\hline \multicolumn{3}{|c|}{ Other complementary foods, median (25th-75th percentile) } & e) 0.90 \\
\hline $\begin{array}{l}\mathrm{kJ} \mathrm{day}^{-1} \\
\mathrm{~kJ} \mathrm{~kg}^{-1} \text { day }^{-1}\end{array}$ & $\begin{array}{c}437(239-906) \\
66(36-140)\end{array}$ & $\begin{array}{l}760(321-1144) \\
105(56-143)\end{array}$ & $\begin{array}{l}0.53 \\
0.67\end{array}$ \\
\hline Breast milk, mea & $\begin{array}{c}n=37(100 \%) \\
(\mathrm{SD})\end{array}$ & $n=35(92 \%)$ & 0.09 \\
\hline $\begin{array}{l}\mathrm{kJ} \mathrm{day}^{-1} \\
\mathrm{~kJ} \mathrm{~kg}^{-1} \text { day }^{-1}\end{array}$ & $\begin{array}{l}984 \pm 519 \\
134 \pm 710\end{array}$ & $\begin{array}{l}917 \pm 477 \\
130 \pm 71\end{array}$ & $\begin{array}{l}0.57 \\
0.73\end{array}$ \\
\hline Total, mean (SD) & $n=37(100 \%)$ & $n=38(100 \%)$ & \\
\hline $\begin{array}{l}\mathrm{kJ} \mathrm{day}^{-1} \\
\mathrm{~kJ} \mathrm{~kg}^{-1} \text { day }^{-1}\end{array}$ & $\begin{array}{r}2268 \pm 582 \\
314 \pm 750\end{array}$ & $\begin{array}{r}2017 \pm 636 \\
280 \pm 840\end{array}$ & $\begin{array}{l}0.08 \\
0.08\end{array}$ \\
\hline
\end{tabular}

SD - standard deviation.

of partially breast-fed infants in other studies in developing countries ${ }^{3}$. Breast milk intake reported in this study was not corrected for insensible water loss during the course of measurement. The systematic negative bias caused by not correcting for insensible water loss is well acknowledged. Given that there were no significant differences between the groups in breast-feeding frequency or duration, corrections would not have had an impact on the difference between groups. Nevertheless, assuming a rate of insensible water loss ${ }^{29}$ of $3 \mathrm{~g} \mathrm{~kg}^{-1} \mathrm{~h}^{-1}$, and given the breast-feeding frequency and duration as well as average weights, breast milk intake would have been underestimated by a maximum of 5\% in both the intervention and control groups at 24 weeks of age.

Table 7 Crude and adjusted length and weight velocity

\begin{tabular}{|c|c|c|c|c|}
\hline & \multicolumn{2}{|c|}{ Length velocity $\left(\mathrm{cm}\right.$ month $\left.{ }^{-1}\right)$} & \multicolumn{2}{|c|}{ Weight velocity $\left(\mathrm{kg} \mathrm{month}^{-1}\right)$} \\
\hline & Crude & Adjusted* & Crude & Adjusted $†$ \\
\hline \multicolumn{5}{|l|}{$16-23$ weeks } \\
\hline Intervention group & $1.80 \pm 0.81 \ddagger$ & $1.79 \pm 0.12 \S$ & $0.51 \pm 0.22 \ddagger$ & $0.51 \pm 0.04 \S$ \\
\hline Control group & $2.11 \pm 0.60 \ddagger$ & $2.16 \pm 0.12 \S$ & $0.45 \pm 0.24 \ddagger$ & $0.44 \pm 0.04 \S$ \\
\hline Difference $(95 \% \mathrm{Cl})$ & $-0.30(-0.65,0.05)$ & $-0.36(-0.70,-0.02)$ & $+0.06(-0.06,0.17)$ & $+0.07(-0.04,0.18)$ \\
\hline$P$-value & 0.09 & 0.03 & 0.31 & 0.22 \\
\hline \multicolumn{5}{|l|}{ 24-31 weeks } \\
\hline Intervention group & $1.84 \pm 0.84 \ddagger$ & $1.85 \pm 0.12 \S$ & $0.25 \pm 0.18 \ddagger$ & $0.26 \pm 0.03 \S$ \\
\hline Control group & $1.35 \pm 0.58 \ddagger$ & $1.34 \pm 0.13 \S$ & $0.28 \pm 0.17 \ddagger$ & $0.27 \pm 0.03 \S$ \\
\hline Difference $(95 \% \mathrm{Cl})$ & $+0.49(0.13,0.85)$ & $+0.51(0.15,0.88)$ & $-0.03(-0.12,0.05)$ & $-0.01(-0.10,0.71)$ \\
\hline$P$-value & $<0.01$ & $<0.01$ & 0.43 & 0.74 \\
\hline \multicolumn{5}{|l|}{$16-31$ weeks } \\
\hline Intervention group & $1.85 \pm 0.42 \ddagger$ & $1.88 \pm 0.07 \S$ & $0.36 \pm 0.14 \ddagger$ & $0.37 \pm 0.03 \S$ \\
\hline Control group & $1.68 \pm 0.43 \ddagger$ & $1.66 \pm 0.07 \S$ & $0.38 \pm 0.17 \ddagger$ & $0.38 \pm 0.03 \S$ \\
\hline Difference $(95 \% \mathrm{Cl})$ & $+0.17(-0.04,0.38)$ & $+0.22(0.02,0.43)$ & $-0.02(-0.10,0.06)$ & $-0.01(-0.09,0.07)$ \\
\hline$P$-value & 0.11 & 0.04 & 0.66 & 0.87 \\
\hline
\end{tabular}

$\mathrm{Cl}$ - confidence interval.

${ }^{*}$ Adjusted for growth that preceded the specified time interval and morbidity during the same time interval.

$\dagger$ Adjusted for morbidity.

$\ddagger$ Mean \pm standard deviation.

$\S$ Mean \pm standard error.

I Intervention minus control. 
On the other hand, the values for breast milk intake reported in this study are remarkably consistent with the findings of another study that was conducted in the same area two years earlier ${ }^{22}$. The likely reasons for this low level of intake include the very early introduction of complementary foods observed in The Congo ${ }^{30}$, which in turn displaces breast milk. The results of the study seem to indicate that amylase-containing complementary foods did not displace breast milk more than the same foods without amylase. This finding is important especially in a context of very low breast milk intake such as this one.

The difference in total energy intake did not reach the level of statistical significance. This study could have lacked statistical power since the sample size calculation was based on energy intakes from gruels alone and not total energy intakes. Given the sample size, 90\% power and type I error of $5 \%$, a difference of $64 \mathrm{~kJ} \mathrm{~kg}^{-1} \mathrm{day}^{-1}$ was detectable, which is much higher than the difference observed.

Other limitations of this study include the lack of reliable compliance rates and the single dietary assessment during the intervention period. We had originally set up a follow-up of flour consumption through short forms to be filled by mothers but data quality restrictions did not allow us to make use of the results. Nevertheless, flour consumption was ascertained during the morbidity visits by reported consumption of packets. Regarding dietary assessment, the weighed food record and test weighing for 24 hours carried out at 24 weeks allowed us to have sufficiently valid and precise information on dietary intake to enable us to compare group means ${ }^{31,32}$.

Linear growth could be affected by several factors including hereditary effects, prenatal growth retardation, morbidity and dietary intakes ${ }^{33}$. Since mothers' heights and infants' birth weights were similar in both groups and given that the analysis took into account morbidity rates, the differences observed in linear growth are most likely due to differences in dietary intakes.

Length velocity between 16 and 24 weeks in the intervention group was lower than that of infants in the control group after adjustment for previous growth and morbidity. This period of decreased length velocity also coincides with higher prevalence and incidence of respiratory illness that have been shown to have a negative effect on growth ${ }^{34,35}$. We have no explanation for this unexpected finding of increased respiratory illness although we cannot entirely rule out the possibility that it is induced by the intervention itself. This possibility seems to be quite unlikely, however, since there are no differences in the incidence and prevalence of respiratory illness later on in the intervention. Even if the length velocity of infants in the intervention group was constrained by respiratory illness between 16 and 24 weeks of age, we believe, as recently reported ${ }^{36,37}$, that the introduction of improved complementary foods before the age of 6 months confers no advantage in terms of growth since neither weight growth nor linear growth was improved.

As to why linear growth between 24 and 32 weeks was improved and not weight, one can speculate that the consumption of a nutrient-dense, well-balanced complementary food in greater quantities provided infants in the intervention group with greater amounts of one or several nutrients which could have limited skeletal growth of infants in the control group rather than energy alone $^{38,39}$. For instance, supplementation trials in Guatemala $^{40}$ and Mexico ${ }^{41}$ have demonstrated the selective positive impact of iron and zinc on linear growth of stunted children. In our study, mean total iron (5.9 \pm 2.9 and $5.0 \pm 2.2 \mathrm{mg} \mathrm{day}^{-1}$ in the intervention and control group, respectively; $P<0.01)$ and zinc $(6.3 \pm 1.9$ and $5.63 \pm 2.0 \mathrm{mg} \mathrm{day}^{-1}$, respectively; $P=0.03$ ) intakes were higher in the intervention group. Although infants in both groups were well within the requirements for zinc, those in the control group fell short of their theoretical requirements for $\operatorname{iron}^{42}$. However, these estimations obviously do not take into account the bioavailability of micronutrients.

The absence of a significant effect on weight could also be explained by the fact that infants in the control group were already close to meeting Butte et al.'s recommendations for energy requirements ${ }^{43}$ and had thus been gaining weight adequately. Indeed 55\% of infants in the control group were below the recommendations instead of the expected $50 \%$.

Between 24 and 32 weeks of age, length velocity of infants in the intervention group was above the NCHS reference. It would have been interesting to continue to monitor length velocity after the age of 32 weeks knowing that children are most vulnerable to growth faltering between the ages of 9 and 12 months ${ }^{44}$. Further investigation is needed to see if the modest difference observed in length velocity has an effect over a longer period of time.

In conclusion, we confirm that increasing the energy density of gruels with amylase facilitates an increase in energy intake from gruels of infants in normal living conditions. This increase in energy density, along with an increase in other nutrients, seems to have been effective in preventing a decrease in length velocity that occurred in infants in the control group after 24 weeks of age. However, further investigation is needed to see if the difference observed in growth has an effect in the long term.

Technological processes allowing the modification of dietary characteristics of complementary foods are not the only solution available for improving the energy and nutrient density of gruels. In Jamaica, the addition of selected ingredients such as milk powder proved to be a cheap and feasible way to improve energy density ${ }^{45}$. However, such ingredients that increase not only macrobut also micronutrient density could be too expensive or 
not readily available in some contexts. Therefore, the use of processes aimed at reducing viscosity such as the addition of amylase could have the potential for further adaptation where local production and distribution systems are available.

\section{Acknowledgements}

We would like to thank the mothers and children who participated in this study. We thank Dr Marie-Claude Dop for her participation in the design of the study and her comments on the manuscript. We are also grateful to Dr Michelle Holdsworth, Dr Bernard Maire and Dr Gérard Rocquelin for their valuable comments. The Institut de Recherche pour le Développement (ex-ORSTOM) funded the study.

\section{References}

1 Dewey KG, Peerson MJ, Heinig MJ, Nommsen LA, Lömmeral B, Lopez de Romana G, et al. Growth patterns of breast-fed infants in affluent (United States) and poor (Peru) communities: implications for timing of complementary feeding. Am. J. Clin. Nutr. 1992; 56: 1012-8.

2 Cohen RJ, Brown KH, Canahuati J, Rivera LL, Dewey KG. Determinants of growth from birth to 12 months among breast-fed Honduran infants in relation to age of introduction of complementary foods. Pediatrics 1995; 96: 504-10.

3 World Health Organization (WHO). Complementary Feeding of Young Children in Developing Countries - A Review of Current Scientific Knowledge. WHO/NUT/98.1. Geneva: WHO, 1998.

4 Brown KH. Complementary feeding in developing countries: factors affecting energy intake. Proc. Nutr. Soc. 1997; 56: 139-48.

5 Mosha AC, Svanberg U. The acceptance and intake of bulkreduced weaning foods: the Luganga village study. Food Nutr. Bull. 1988; 10: 50-3.

6 Lukmanji Z, Ljungqvist BG, Hedqvist F, Elisonguo C. Child feeding patterns in Tanzania with reference to feeding frequency and dietary bulk. In: Alnwick D, Moses S, Schmidt OG, eds. Improving Young Child Feeding in Eastern and Southern Africa: Household Level Food Technology. Ottawa: IDRC, 1988; 341-53.

7 Sanchez-Grinãn MI, Peerson JM, Brown KH. Effect of dietary energy on total ad-libitum energy consumption by recovering malnourished children. Eur. J. Clin. Nutr. 1992; 46: 197-204.

8 Rahman MM, Islam MA, Mahalanabis D, Biswas E, Majid N, Wahed MA. Intake from an energy dense porridge liquefied by amylase of germinated wheat: a controlled trial in severely malnourished children during convalescence from diarrhoea. Eur. J. Clin. Nutr. 1994; 48: 46-53.

9 Stephenson D, Gardner JM, Walker SP, Ashworth A. Weaning-food viscosity and energy density: their effects on ad libitum consumption and energy intakes in Jamaican children. Am. J. Clin. Nutr. 1994; 60: 465-9.

10 Brown KH, Sanchez-Griñan M, Perz F, Peerson JM, Ganoza L, Stern JS. Effects of dietary energy density and feeding frequency on total daily energy intakes of recovering malnourished children. Am. J. Clin. Nutr. 1995; 62: 13-8.

11 Darling JC, Kitundu JA, Kingamkono RR, Msengi AE, Mduma $\mathrm{B}$, Sullivan KR, et al. Improved energy intakes using amylase-digested weaning foods in Tanzanian children with acute diarrhea. J. Pediatr. Gastroenterol. Nutr. 1995; 21 . $73-81$.

12 Mitra AK, Rahman MM, Mahalanabis D, Patra FC, Wahed MA Evaluation of an energy-dense meal liquefied with amylase of germinated wheat in children with acute watery diarrhoea: a randomized controlled clinical trial. Nutr. Res. 1995; 15: 939-51.

13 Donnen P, Dramaix M, Brasseur D, Bitwe Mihanda R, Fazili $S$, Trèche $S$. High energy density gruels in the treatment of hospitalized children suffering from mainly protein malnutrition in Zaire. Food Nutr. Bull. 1996; 17: 145-53.

14 Den Besten L, Glatthaar II, Ijsselmuiden CB. Adding alphaamylase to weaning food to increase dietary intake in children. A randomised controlled trial. J. Trop. Pediatr. 1998; 44: 4-9.

15 Bennett VA, Morales E, Gonzalez J, Peerson JM, Lopez de Romana G, Brown KH. Effects of dietary viscosity and energy density on total daily energy consumption by young Peruvian children. Am. J. Clin. Nutr. 1999; 70: 285-91.

16 Gopaldas T, Mehta P, Patil A, Gandhi H. Studies on reduction in viscosity of thick rice gruels with small quantities of an amylase-rich cereal malt. Food Nutr. Bull. 1986; 8: 68-73.

17 John C, Gopaldas T. Reduction in the dietary bulk of soyafortified bulgur wheat gruels with wheat-based amylase rich food. Food Nutr. Bull. 1988; 10: 50-3.

18 Gopaldas T, Mehta P, John C. La réduction du volume des gruaux de sevrage traditionnels en Inde. In: Alnwick D, Moses S, Schmidt OG, eds. Improving Young Child Feeding in Eastern and Southern Africa: Household Level Food Technology. Ottawa: IDRC, 1988; 375-85.

19 Gopaldas T, John C. Evaluation of a controlled 6 months feeding trial on intake by infants and toddlers fed a high energy-low bulk gruel versus a high energy-high bulk gruel in addition to their habitual home diet. J. Trop. Pediatr. 1992; 38: 278-83.

20 Marquis GS, Lopez T, Peerson JM, Brown KH. Effect of dietary viscosity on energy intake by breast-fed and nonbreast-fed children during and after acute diarrhoea. $\mathrm{Am}$. J. Clin. Nutr. 1993; 57: 218-23.

21 Delpeuch F, Dop MC. A review of young child feeding practices in Africa and the Middle East: need for improvement. In: Dop MC, Benbouzid D, Trèche S, De Benoist B, Verster A, Delpeuch F, eds. Complementary Feeding of Young Children in Africa and the Middle East. WHO/NHD/99.3, WHO/AFRO/NUT/99.4. Geneva: World Health Organization, 1999.

22 Dop MC, Norton R, Mbemba F, Trèche S. Breast milk intakes and feeding practices in urban Congo [abstract]. Presented at the 7th International Conference of the International Society for Research in Human Milk and Lactation, La Trinidad, Tlaxcala, Mexico, 24-26 July 1995.

23 Martin-Prével Y, Delpeuch F, Traissac P, Massamba JP, Adoua-Oyila G, Coudert K, et al. Deterioration in the nutritional status of young children and their mothers in Brazzaville, Congo, following the 1994 devaluation of the CFA franc. Bull. World Health Org. 2000; 78: 108-18.

24 Delpeuch F, Martin-Prével Y, Fouéré T, Traissac P, Mbemba F, Ly $\mathrm{C}$, et al. Complementary nutrition for the young child following the devaluation of the CFA franc (African Financial Community): 2 case studies in the Congo and Senegal urban environment. Bull. World Health Org. 1996; 74: 67-75.

25 Victora CG, Morris SS, Barros FC, Horta BL, Weiderpass E, Tomasi E. Breast-feeding and growth in Brazilian infants. Am. J. Clin. Nutr. 1998; 67: 452-8.

26 Souci SW, Fachman W, Kraut H. Food Composition and Nutrition Tables, 5th ed. Stuttgart: Medpharm Scientific Publisher, CRC Press, 1994.

27 Brown KH, Black RE, Robertson AD, Akhtar NA, Ahmed G, Becker S. Clinical and field studies of human lactation: 
methodological considerations. Am. J. Clin. Nutr. 1982; 35 : 745-56.

28 Scanlon S, Alexander MPH, Serdula MK, Davis MK, Bowman BA. Assessment of infant feeding: the validity of measuring milk intake. Nutr. Rev. 2002; 60: 235-51.

29 Dewey KG, Heinig MJ, Nommser LA, Lömmerdal B Adequacy of energy intake among breast-fed infants in the Darling study, relationship to growth velocity, morbidity and activity levels. J. Pediatr. 1991; 119: 538-47.

30 Cornu A, Trèche S, Massamba JP, Massamba J, Delpeuch F Weaning practices and nutritional interventions in Congo [in French]. Santé 1993; 3: 168-77.

31 Thompson FE, Byers T. Dietary Assessment Resource Manual. J. Nutr. 1994; 124(Suppl. 11): S2245-317.

32 Black RE, Prentice AM, Goldberg GR. Measurement of total energy expenditure provide insights into the validity of dietary measurements of energy intake. J. Am. Diet. Assoc. 1993; 93: 572-9.

33 Waterlow JC. Causes and mechanisms of linear growth retardation (stunting). Eur. J. Clin. Nutr. 1994; 48(Suppl. 1): S1-4.

34 Lopez de Romaña G, Brown KH, Black RE, Kanashiro HC. Longitudinal studies of infectious diseases and physical growth of infants in Huascar, an underprivileged peri-urban community in Lima, Peru. Am. J. Epidemiol 1989; 129: 769-84.

35 Smith TA, Lehmann D, Coakley C, Spooner V, Alpers MP Relationships between growth and acute respiratory infections in children aged less than $5 \mathrm{y}$ in a highland population of Papua New Guinea. Am. J. Clin. Nutr. 1991; 53: 963-70.

36 Cohen RJ, Brown KH, Canahuati J, Landa Rivera L, Dewey KG. Effects of age of introduction of complementary foods on infant breast milk intake, total energy intake, and growth: a randomised intervention study in Honduras. Lancet 1994; 344: 288-93.

37 Dewey KG, Cohen RJ, Brown KH, Landa Rivera L. Age of introduction of complementary food and growth of term, low birth weight breastfed infants: a randomized intervention study in Honduras. Am. J. Clin. Nutr. 1999; 69: 679-86.

38 Allen LH. Nutritional influences on linear growth: a general review. Eur. J. Clin. Nutr. 1994; 48(Suppl. 1): S75-89.

39 Golden MHN. The role of individual nutrient deficiencies in growth retardation of children as exemplified by zinc and protein. In: Waterlow JC, ed. Linear Growth Retardation in Less Developed Countries. New York: Raven Press, 1988; $143-64$.

40 Rivera JA, Ruel MT, Santizo MC, Lönnerdal B, Brown KH. Zinc supplementation improves the growth of stunted rural Guatemalan infants. J. Nutr. 1998; 128: 556-62.

41 Rivera JA, González-Cossío T, Flores M, Romero M, Rivera M, Téllez-Rojo M, et al. Multiple micronutrient supplementation increases the growth of Mexican infants. Am. J. Clin. Nutr. 2001; 74: 657-63

42 National Research Council. Recommended Dietary Allowances, 10th ed. Washington, DC: National Academy Press, 1991.

43 Butte NF, Wong WW, Hopkinson JM, Heinz CJ, Mehta NR, Smith EO'B. Energy requirements derived from total energy expenditure and energy deposition during the first $2 \mathrm{y}$ of life. Am. J. Clin. Nutr. 2000; 72: 1558-69.

44 Dewey KG. Cross-cultural patterns of growth and nutritional status of breast-fed infants. Am. J. Clin. Nutr. 1998; 67: 10-7.

45 Meeks Gardner J, Walker SP, Gavin KA, Ashworth A. Complementary foods in Jamaica: viscosity, energy density and feeding practices. Public Health Nutr. 2002; 5(2): 295-302. 